"Protection of Nature. Atmosphere. Rules for the Establishment of Maximum Allowable Emissions of Hazardous Substances in the Atmosphere of the Industrial Enterprises"]. Moscow : Izdatelstvo standartov ; 1980 : 89-94; 105-112

(in Russian).

7. Pro zatverdzhennia normatyviv hranychno dopustymykh vykydiv zabrudniuiuchykh rechovyn iz statsionarnykh dzherel : nakaz Minpryrody Ukrainy № 309 vid 27.06.2006. [On the Adoption of the Standards of Maximum Allowable Emissions from the Stationary Sources : Order of the Ministry of Nature of Ukraine № 309, 27.06.2006]. URL :http://zakon5.rada. gov.ua/laws/show/z0912-06 (in Ukrainian).

8. Ciganek M. and Neca J. Veterinary medicine. 2008 ; 53(12) : 641-651.

9. Turos O.I. Mozhlyvosti vykorystannia metodolohii otsinky ryzyku v poperedzhuvalnomu ta potochnomu sanitarnomu nahliadi [Possibilities of the Use of the Methodology for Risk Assessment in Preventive and Routine Sanitary Inspection]. In : Planuvannia ta zabudova naselenykh mists: aktualni sanitarno-hihiienichni ta ekolohichni problem i shliakhy ikh vyrishennia [Planning and Building of the Settlements: Actual Sanitary-and-Hygienic and Ecological Problems and the Ways for their Solution: Conf. Abstracs]. Kyiv, 2007 : 25-26 (in Ukrainian).

10. Derzhavni sanitarni pravyla okhorony atmosfernoho povitria naselenykh mists (vid zabrudnennia khimichnymy ta biolohichnymy rechovynamy) : DSP-201-97 [State Sanitary Rules for the Protection of Ambient Air of the Settlements (from the Contamination with Chemical and Biological Substances) : DSP-201-97]. Kyiv ; $1997: 57 \mathrm{p}$.

(in Ukrainian).

11. Ragoysha A.A. Biulleten khimicheskoy informatsii. 2009 ; $1: 6-8$ (in Russian).

12. Review of the Reference Dose and Reference Concentration Process. EPA/630/P02/002F, December 2002 Final Report. 2002 : 23-28.

Надійшло до редакції 18.01.2018

\title{
NATURAL MOVEMENT OF THE POPULATION AND CHILDBEARING ACTIVITY [REEIONAL ASPECT)
}

Kalynychenko D.O.

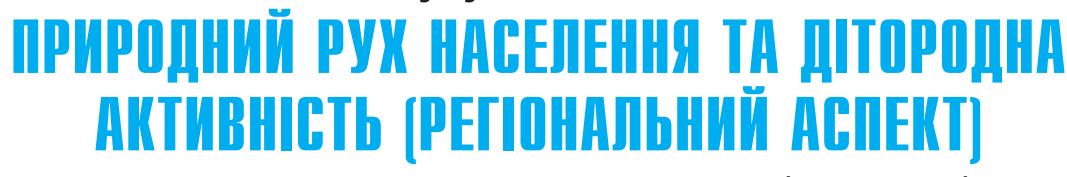

КАЛИНИЧЕНКО Д. О.

Сумський державний

педагогічний університет ім. А. С. Макаренка irinakalinichenko2017@ gmail.com

УДК 614.1+314.8.062.2

Ключові слова: народжуваність, природний приріст, репродуктивний вік, демографічні показники, населення, смертність.

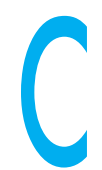
еред регіональних цільових орієнтирів, що пропонуються ВОО3, пріоритетне місце посідає підвищення середньої тривалості життя та рівня благополуччя населення $[1,2]$. Різниця у показниках очікуваної тривалості життя при народженні між країнами 3 найнижчими і найвищими рівнями становить 16 років, показники материнської смертності різняться між країнами у 42 рази, є істотні відмінності у тривалості життя між окреми-

ЕСТЕСТВЕННОЕ ДВИЖЕНИЕ НАСЕЛЕНИЯ И ДЕТОРОДНАЯ

АКТИВНОСТЬ (региональный аспект)

Калиниченко Д.О.

Сумской государственный педагогический университет им. А.С. Макаренко, г. Сумы, Украина

Медико-демографическая ситуация, сложившаяся в последние годы в Украине, свидетельствует о неудовлетворительном состоянии здоровья населения, характеризуется высокими показателями заболеваемости, низкой рождаемостью и высоким уровнем смертности. Цель работы: исследовать современные региональные особенности естественного движения населения и определить типологические группы районов по результатам детородной активности. Материалы и методы исследования. Для анализа демографической ситуации в Украине и Сумской области использовали данные Всеукраинской переписи населения, Государственной службы статистики Украины. Выполнено ранжирование районов Сумской области по показателям естественного прироста (сокращения) населения в 2014-2016 годах. Результаты исследований. Для анализа демографических процессов в области проранжированы трехлетние изменения численности населения каждого районного центра. В ходе исследования установлены районы с относительно благоприятной, напряженной и кризисной демографической ситуацией. Трехлетнее уменьшение численности населения Сумской области происходило преимущественно за счет населения сельской местности $(-3,13)$ по сравнению с населением городских поселений $(-1,09)$.

Установлено, что во всех районах области наблюдается уменьшение общей численности населения, однако факторы демографических процессов разные. Отдельные районы области имеют похожую картину демографических изменений, что позволило по показателям рождаемости и смертности населения выделить четыре типа районов области. Демографическое районирование может служить основой конкретных перспективных медико-социальных мероприятий для указанных регионов. Сумская область относится к регионам с низким показателем среднего количества рожденных детей женщинами в возрасте от 15 лет и старше (2,0-2, 1 ребенка по сравнению с западными областями Украины, где средняя рождаемость более 2,2 ребенка). В период раннего репродуктивного возраста (20-24 года) женщин Украины и Сумской области среднее количество рожденных детей на 1 женщину с высшим образованием составляет 1,09 и 1,06 соответственно. Среди женщин фертильного возраста и в городах, и в селах наиболее распространенной является репродуктивная установка на рождение двух детей.

Ключевые слова: рождаемость, естественный прирост, репродуктивный возраст, демографические показатели, население, смертность.

ㄷ Калиниченко Д. О. СТАТТЯ, 2018. 
у соціально-економічній сфері життя населення зниженням показника народжуваності [4]. Показник природного приросту населення в Україні залишається від'ємним, а сумарний коефіцієнт народжуваності становить лише 1,5 дитини на одну жінку, тоді як для досягнення рівня простого відтворення населення він має становити 2,1 [3, 5].

Загальний природний та міграційний приріст (скорочення)

ми соціальними групами в усіх країнах регіону [3].

Останнім часом в Україні склалася несприятлива медико-демографічна ситуація, що свідчить про незадовільний стан здоров'я населення, який характеризується високими показниками захворюваності, низькою народжуваністю та високим рівнем смертності. Так, середня тривалість життя в Україні на 5 років нижча, ніж в Європейському регіоні і на 9 років нижча, ніж у країнах Європейського Союзу.

За даними Державного комітету статистики України, лише 15\% загальної кількості наших громадян є старшими за 65 років. Порівняно 3 країнами Європи смертність населення в Україні практично вдвічі вища (у 2014 році - 14,7 випадків на 1000 населення проти 6,7 у країнах-членах Європейського Союзу) [3].

Такі характеристики здоров'я населення вимагають нових підходів до розробки регіональних програм у галузі громадського здоров'я на основі аналізу і співставлення демографічного розвитку регіонів в умовах децентралізації управління у державі.

Питання негативних демографічних тенденцій не $€$ новим, що визначається необхідністю обґрунтування заходів профілактики соціально значимих хвороб, виявлення чинників ризику погіршення стану здоров'я та зменшення природного скорочення населення. Період 2008-2013 рр. характеризувався сприятливою демографічною динамікою в Україні зі зростанням показника природного приросту населення. Проте позитивні зміни не виявилися сталими, дітородна активність як в Україні, так і у Сумській області відреагувала на нестабільність населення визначають загальну чисельність народонаселення, забезпечення держави трудовими і репродуктивними ресурсами.

Однак демографічні процеси залежать від соціально-економічних чинників, що відбуваються у світі й конкретній країні, тому для характеристики природного руху населення використовуються коефіцієнти народжуваності, смертності і природного приросту [6].

Кілька десятиліть тому науковцями здійснювалося демографічне районування України (Піскунов В.П., Стешенко В.С., 1975) $з$ метою територіальної диференціації соціально-демографічних процесів, виявлення відмінності показників природного руху та народжуваності. У ході попередніх досліджень було виділено чотири демографічні зони, проте існує необхідність виконання дослідження окремо по кожній області, враховуючи сучасні соціально-економічні та природні регіональні особливості. Актуальність міжрегіонального співставлення показників демографічного розвитку, визначення рейтингу районів $€$ важливим кроком для оцінки ефективності програми децентралізації управляння у регіонах.

Метою роботи було досліливості природного руху населення та визначити типологічні групи районів за результатами дітородної активності.

Матеріали і методи досліджень. Для аналізу демографічної ситуації в Україні та у Сумській області використовували дані Всеукраїнського перепису населення 2001 року [7], Державної служби статистики України [8, 9].

Виконано ранжування районів Сумської області за дити сучасні регіональні особ- показниками природного приросту (скорочення) населення у 2014-2016 роках.

У роботі використовувалися бібліографічний, аналітичний, порівняльний методи дослідження. Для оцінки міжгрупових відмінностей при статистичній обробці отриманих результатів використовували t-критерій Ст'юдента (відмінності вважалися достовірними 3 рівнем значущості $p<0,05)$.

Результати дослідження та їх обговорення. За кількістю населення Україна входить до п'ятірки найбільших країн Європи (Велика Британія, Італія, Німеччина, Франція). Проте з 1994 року відбувається скорочення чисельності населення, що зумовлено поступовим зниженням показника народжуваності і зростанням смертності $[5,10]$.

За даними офіційної статистики, за 25 останніх років населення України скоротилося більш ніж на 9 млн. осіб. 1991 року в Україні налічувалося 51,944 млн. осіб, станом на 1 січня 2016 р. - 42,760 млн. осіб, а на початок 2017 року 42584500 осіб [7]. В Україні співвідношення чоловіків і жінок становило $46,3 \%$ та 53,7\% відповідно. У Сумській області зберігаються аналогічні пропорції (46,0\% та 54,0\% відповідно).

Згідно 3 Всеукраїнським переписом населення, станом на 5 грудня 2001 року, кількість населення України становила 48 млн. 457 тис. осіб, що на 3 млн. менше, ніж у 1989 році. Протягом наступних 16 років населення України зменшилося ще на 5 млн. 696 тис. осіб (з 48457000 осіб у 2001 році до 42760516 осіб у 2016), що у динаміці 27 років становить $16,9 \%$ від кількості населення 1989 року [7, 8]. Населення Сумської області, за даними перепису, зменшилося від 1432700 до 1299700 осіб (1989 та 2001 роки), а за даними Державної служби статистики України, на кінець 2016 року становило 1113256 осіб. Зменшення становить 22,3\% від кількості населення Сумщини у 1989 році, що свідчить про більш інтенсивні темпи депопуляції в області порівняно з загальнодержавними тенденціями $[7,8]$. Причому пито- 
ма вага міграційних процесів в Україні становить лише 8,43\% від загального приросту (скорочення) населення, решта припадає на природній приріст (скорочення) населення країни. У Сумській області 9,56\% загального приросту залежить від міграційних процесів [8].

За 2014-2016 роки чисельність населення в усіх районних центрах Сумської області зменшувалася. Для аналізу демографічних змін в області було проранжовано трирічний приріст кількості населення кожного районного центру. Аналіз скорочення чисельності наявного населення у розріз районів області дозволив виокремити регіони 3 відносно сприятливою демографічною ситуацією (3), напруженою (2) і кризовою (1). Найбільше виражена депопуляція зі значним зменшенням населення спостерігається

Конотопському (-4,37\%), Буринському $(-3,98 \%)$, Глухівському $(-3,81 \%)$ районах. Напружена демографічна ситуація реєструється у Липоводолинському $(-2,83 \%)$, Путивльському $(-2,68 \%)$, Ceрединобудському (-2,58\%), Кролевецькому $(-2,47 \%)$ районах. Незначне зменшення кількості населення встановлено у м. Суми $(-0,46 \%)$ та Сумському районі $(-0,40 \%)$, що можна пояснити урбанізацією та меншою міграцією із обласного центру.

Трирічне зменшення чисельності наявного населення Сумської області відбувалося переважно за рахунок сільського населення $(-3,13)$, ніж міського $(-1,09)$, хоча показник державного рівня свідчить про баланс вказаного показника за критерієм "місце поселення". У районах з кризовою демографічною ситуацією скорочення чисельності населення відбувалося аналогічно, за рахунок мешканців сільської місцевості, за винятком Роменського району, де зменшення населення не залежало від місця проживання.

Зменшення чисельності населення зумовлене загальним стійким природним перевищенням кількості смертей над кількістю новонароджених та значними міграційними процесами, що є характерним для

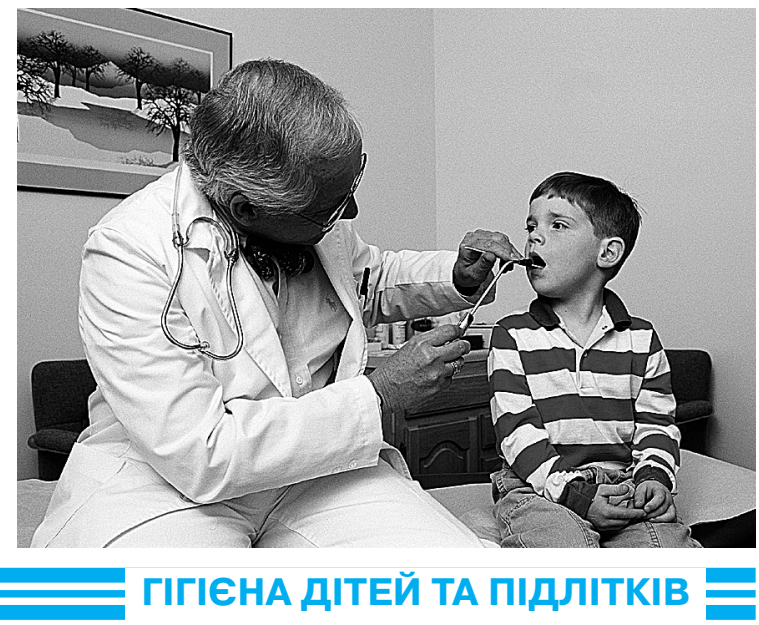

загальнодержавної демографічної статистики. За останні роки чисельність населення Сумської області, як і України загалом, змінювалася нелінійно, а характеризувалася періодами уповільнення скорочення населення (3 2005 по 2012 рік) $з$ подальшим погіршенням показника природного приросту (скорочення) до -4,36 по Україні і -8,87 - у Сумській області. Уповільнення природного скорочення населення до 2012 року можна пояснити таким чином:

$\square$ збільшенням чисельності жінок фертильного віку, які народилися на початку 1980-х років;

$\square$ зменшенням кількості смертей серед нечисленного покоління осіб 1940-х років народження, які перетнули 60тирічну межу за вказаний період [6];

$\square$ репродуктивний ресурс було вичерпано, коли потенційними матерями стали дівчата, які народилися у 1990-х роках, у період різкого зниження народжуваності;

口 до 2012 року у державі проводилася активна соціально-демографічна політика, яка в останні роки нівелюється складними соціально-економічними та політичними негараздами

Доведено, що Сумська область належить до групи найстаріших у демографічному відношенні областей України, серед яких Чернігівська, Вінницька, Житомирська, Черкаська [10]. Показник смертності серед дорослого населення області становить 16,9, що на 18,93\% перевищує державний показник $(13,7)$.

Крім того, співвідношення чоловіків та жінок (чисельність чоловіків на 1000 жінок) у Сумській області коливається від 840 до 850, що є неспри- ятливим Фоном репродуктивних ресурсів.

Имовірно, вказаними причинами можна пояснити той факт, що у Сумській області у 2016 році реєструвався найвищий по Україні (після Чернігівської області -10,3) показник природного скорочення населення $-8,87$ на 1000 населення.

3 використанням загальноприйнятих демографічних показників за 2014-2016 рр. (народжуваність, смертність населення) та розрахунку їх різниці у динаміці трьох років (\%) було виокремлено чотири типи районів Сумської області: І тип характеризувався значним зниженням показника народжуваності і приростом показника смертності понад 2,0\% (Недригайлівський, Тростянецький райони); II тип - незначні коливання показника народжуваності і збільшення показника смертності населення (Буринський, Липоводолинський райони); III тип зниження нороджуваності і приріст показників смертності до 1,3\% (Глухівський, Конотопський, Охтирський райони); IV тип - зниження показника народжуваності і зниження показника смертності (Білопільський, Великописарівський, Краснопільський, Кролевецький, Лебединський, Путивльський, Роменський, Серединобудський, Сумський, Шосткинський, Ямпільський райони).

За даними Всеукраїнського перепису 2001 року, кількість населення від 0 до 9 років становила 4533000 осіб. Це той контингент $(9,4 \%$ населення України), який нині складає вікову групу від 17 до 26 років, що, за визначенням ВООЗ, $€$ групами раннього та активного репродуктивного періоду, питома вага якої на $5,9 \%$

\section{Rovirovimes \& Ileasmi №2 2018}


Сумській області, частка жінок, що народили одну дитину, становить $35,59 \%$ та $34,03 \%$ відповідно. При цьому у містах майже удвічі більше жінок мають одну дитину $(41,85 \%$ в Україні та 40,45\% у Сумській області), ніж у сільських поселеннях (23,43\% та 23,24\% відповідно). Найбільш поширеною $є$ репродуктивна установка на народження двох дітей і у містах, і у селах.

За даними Всеукраїнського

менше даних перепису населення 1989 року.

Загальновідомо, що інтегральним показником Р3 населення $€$ показник народжуваності. Сумська область належить до регіонів з низьким показником середньої кількості народжених дітей жінками віком 15 років і старших, який становить від 2,0 до 2,1 дитини порівняно 3 західними областями України, де середня народжуваність - понад 2,2 дитини.

За даними опитування серед жінок з вищою освітою, середня кількість народження дітей у віці 15-19 років на 1 жінку становила 1,03 як в Україні, так і у Сумській області, серед жінок з загальною середньою освітою - 1,06 і 1,04 відповідно. У період раннього репродуктивного віку (20-24 роки) жінок України і Сумської області середня кількість народжених дітей на 1 жінку з вищою освітою становила 1,09 і 1,06 відповідно. Розрахунковий показник для жінок України 3 загальною середньою освітою становив 1,22 і 1,17 - для жінок Сумщини. Кількість дітей на 1 жінку у Сумській області $€$ меншою, ніж за загальнодержавним показником, вирівнювання досягається у наступній віковій групі 25-29 років $(1,25$ та 1,22), що можна пояснити трансформацією вікової моделі репродуктивних установок 3 перенесенням дітородної активності на вікову групу 25-29 років у Сумській області, що характеризує регіональні особливості порівняно з західними областями України, в яких зберігається перевага багатодітності, більш рання дітородна активність, непопулярність абортів та позашлюбних народжень дітей.

За даними перепису населення, як в Україні, так і у перепису населення, 23,7 млн. осіб перебували у шлюбі. Зокрема, у віковій групі 20-24 роки 24,8\% чоловіків перебували у зареєстрованому або незареєстрованому шлюбі, серед жінок вказаної вікової групи - 48, 1\%. Кількість розлучень серед чоловіків становила 1,6\%, серед жінок - 5,3\% відповідного населення.

В останнє десятиліття підвищилася частка позашлюбних народжень. За анамнестичними даними жінок Сумського обласного перинатального центру, 33,7\% опитаних народжують дітей, не перебуваючи у зареєстрованому шлюбі. Збільшення таких випадків зумовлене не тільки зростанням позашлюбної дітородної активності, але й поширенням незареєстрованих шлюбів, що мають тенденцію до збільшення. Частка жінок, які народжують дітей поза шлюбом, найвища у ранньому репродуктивному віці, що часто $€$ наслідком небажаної вагітності. При цьому питома вага позашлюбних народжень $€$ вищою серед жінок сільської місцевості порівняно з жінками міських поселень і найчастіше зустрічається під час народження першої дитини.

\section{Висновки}

У ході дослідження встановлено райони 3 відносно сприятливою, напруженою і кризовою демографічною ситуацією. Трирічне зменшення чисельності наявного населення у Сумській області відбувалося переважно за рахунок сільського населення $(-3,13)$, ніж населення міських поселень $(-1,09)$. Встановлено, що в усіх районах області спостерігається зменшення загальної чисельності населення, проте чинники демографічних процесів різні. Окремі райони області мають схожу картину демографічних змін, що дало змогу за показниками народжуваності та смертності населення виокремити чотири типи районів області. Демографічне районування може слугувати підґрунтям конкретних перспективних медико-соціальних заходів для означених регіонів.

Сумська область належить до регіонів з низьким показником середньої кількості народжених дітей жінками віком 15 років і старших, який становить від 2,0 до 2,1 дитини порівняно 3 західними областями України, де середня народжуваність - більше 2,2 дитини. у період раннього репродуктивного віку (20-24 роки) жінок України і Сумської області середня кількість народжених дітей на 1 жінку 3 вищою освітою становить 1,09 і 1,06 відповідно. Серед жінок фертильного віку і у містах, і у селах найбільш поширеною $€$ репродуктивна установка на народження двох дітей. Питома вага групи жінок, які народжують дітей поза шлюбом, найвища у ранньому репродуктивному віці, що часто $€$ наслідком небажаної вагітності.

ЛІТЕРАТУРА

1. Здоровье 2020 : Основы Европейской политики поддержки государства и общества в интересах здоровья и благополучия. Copenhagen : WHO Regional Office for Europe, 2012. URL :

http://www. euro.who.int/_data /assets/pdf file/0018/215433/ Health2020-Short-

Rus.pdf?ua=1

2. Wismar D.V.M., Lin V., Jones C.M. et al. Intersectoral governance for health in all policies. Structures, actions and experiences. Copenhagen : WHO Regional Office for Europe, 2012. URL : http://www.euro.who.int/_data

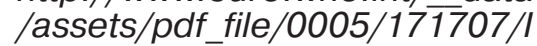
ntersectoral-governance-forhealth-in-all-policies.pdf.

3. Гущук I.В. Деякі питання розбудови системи громадського здоров'я України // Довкілля та здоров'я. 2016. № 4. С. 75-79.

4. Курило І.О., Аксьонова С.Ю., Крімер Б.О. Народжуваність та материнство в Україні: регіональний аспект // Демографія та соціальна 
due to the rural population (-3.13) in comparison with the population of urban settlements $(-1.09)$. Atotal number of the population was established to be observed in all districts of the region but the factors of demographic processes were different. Isolated districts of the region have a similar picture of demographic changes that made it possible to distinguish four types of districts in the region according to the indicators of birthrate and mortality of the population. Demographic division into districts can serve as a basis for specific perspective medico-social measures for the mentioned regions. Sumy region belongs to the regions with a low indicator of average number of born children by the women at the age of 15 years old and older (2.0-2.1 children in comparison with the western regions of Ukraine where the average birthrate is more than 2.2 children). In the period of early reproductive age (20-24 years old) of the women of Ukraine and Sumy region, the average number of born children per 1 woman with the higher education makes up 1.09 and 1.06 respectively.

The reproductive policy on the birth of two childrens is the most common one among the women of fertile age both in cities and in villages.

Keywords: birthrate, natural increase, reproductive age, demographic indicators, population, death rate. економіка. 2016. № 1 (26). C. 65-79.

5. Ціборовський О.М. Здоров'я населення і фактори ризику, що впливають на його стан, як об'єкт управління (огляд літератури) // Україна. Здоров'я нації. 2015. № 2 (34). С. 13-19.

6. Лібанова Е.М., Шевчук П.Є. Оцінка демографічної політики за допомогою поздовжніх і поперечних показників народжуваності // Україна: аспекти праці. 2008. № 2. C. 25-31.

7. Динаміка населення України за даними переписів населення (графічний матеріал). URL : http://2001.

ukrcensus.gov.ua/results/demo grafic population/graphic\#m1.

8. Чисельність наявного населення України на 1 січня 2016 року / Державна служба статистики України. Київ, 2016. $85 \mathrm{c}$.

9. Демографічна та соціальна статистика. Населення та міграція. URL : http://www.ukrstat.gov.ua/.

10. Щорічна доповідь про стан здоров'я населення, санітарно-епідемічну ситуацію та результати діяльності системи охорони здоров'я України. 2015 рік / за ред. Шафранського В.В. ; МO3 України; ДУ "УІСД МОЗ
України". Київ, 2016. С. 10-23. REFERENCES

1. Health 2020: a European Policy Framework Supporting Action Across Government and Society for Health and Wellbeing. WHO Regional Office for Europe. 2012. URL :

http://www.euro.who.int/_data /assets/pdf file/0006/199536/ Health2020-Short.pdf?ua =

2. Wismar D.V.M., Lin V., Jones C.M. et al. Intersectoral Governance for Health in All Policies. Structures, Actions and Experiences. Copenhagen : WHO Regional Office for Europe, 2012. URL :

http://www.euro.who.int/_data /assets/pdf file/0005/17 1707/I ntersectoral-governance-forhealth-in-all-policies. pdf.

3. Hushchuk I.V. Dovkillia ta zdorovia. 2016 ; 4 : 75-79

(in Ukrainian).

4. Kurylo I.O., Aksonova S.Yu., Krimer B.O. Demohrafiia ta sotsialna ekonomika. 2016 ; 1 (26) ; 65-79(in Ukrainian).

5. Tsiborovskyi O.M. Ukraina. Zdorovia natsii. 2015 ; 2 (34) : 13-19 (in Ukrainian).

6. Libanova E. and Shevchuk P.Ye. Ukraina: aspekty pratsi. 2008 ; 2 : 25-31 (in Ukrainian).

7. Dynamika naselennia Ukrainy za danymy perepysiv naselennia (hrafichnyi material) [The Dynamics of the
Population of Ukraine According to the Population Census Data (graphic material)]. URL :http://2001.ukrcensus.gov.ua/ results/demografic_population/graphic\#m 1 (in Ukrainian).

8.Derzhavna sluzhba statystyky Ukrainy. Chyselnist naiavnoho naselennia Ukrainy na 1 sichnia 2016 roku [The Number of the Existing Population of Ukraine as of January 1, 2016]. Kyiv ; 2016 : 85 p. (in Ukrainian).

9.Demohrafichna ta sotsialna statystyka. Naselennia ta mihratsiia [Demographic and Social Statistics. Population and Migration]. URL :

http://www.ukrstat.gov.ua/

(in Ukrainian).

10. Shchorichna dopovid pro stan zdorovia naselennia, sanitarno-epidemichnu sytuatsiiu ta rezultaty diialnosti systemy okhorony zdorovia Ukrainy. 2015 rik [Annual Report on the State of Health of the Population, Sanitary and Epidemic Situation and the Results of Activity of the Healthcare System of Ukraine. 2015] / edited by

Shafranskyi V.V. ; The Ministry of Healthcare of Ukraine ; SI

"Ukrainian Institute for Strategic Studies of the Ministry of Healthcare of Ukraine". Kyiv ; 2016 : 10-23 (in Ukrainian). Надійшло до редакції 22.02.2018 